\title{
Mengungkap Arti Perilaku Etis Menurut Fresh Graduate Akuntansi
}

\author{
Khoirin Azaro ${ }^{1, *}$, Kurnia Ekasari ${ }^{2}$, and Kartika Dewi Sri Susilowati ${ }^{3}$ \\ ${ }^{1}$ Akuntansi, Politeknik Negeri Malang, khoirinazaro97@gmail.com, Indonesia \\ ${ }^{2}$ Akuntansi, Politeknik Negeri Malang,kurnia_es@yahoo.com.au,Indonesia \\ ${ }^{3}$ Akuntansi, Politeknik Negeri Malang, kartikadewi@gmail.com, Indonesia
}

\begin{abstract}
This is the field of study that deals with accounting ethics. This turns out to be even more problematic because the emergence of cases involving the accounting profession within a few years has disfigured the credibility of the accounting profession. Every ethical or unethical behavior carried out by accountants depends on each individual. One of the simplest ways of tackling this problem is the presence of education about ethical awareness of accounting skills, especially in a business context that requires relevant reporting. The overall goal of this work was to find out how the meaning of ethical behavior according to accounting fresh graduates. This study uses qualitative approach through interpretative. For this study, we analyzed the data collected from interview. There were 4 participants in this research. From the results, it is clear that ethics in concept and practice is not much different and ethics is something that must appear in every aspect of life. Ethics must be present in individuals and ethics becomes important in the work as a basis for take an action. This conclusion follows from the fact that ethics education influences the accounting practices of fresh graduate accounting.
\end{abstract}

Keyword: ethics, fresh graduate, interpretative, ethics, ethical behaviour

*Corresponding author. E-mail: khoirinazaro97@gmail.com 


\section{Pendahuluan}

Etika menjadi sebuah topik penting yang perlu ditekankan kepada seluruh aspek kehidupan. Berinteraksi dengan masyarakat, menuntut ilmu didunia pendidikan, bekerja sebagai pengusaha hingga bekerja pada sebuah organisasi tak akan pernah terlepas dari etika. Baik, buruk, benar dan salah merupakan sebuah konsep dari etika. Etika adalah beberapa prinsip moral yang menjadi landasan tentang apa yang baik dan buruk bagi indivdu dan masyarakat (Furqany, Laladyn, dan Mulyany, 2016). Tidak semua yang diangap baik pada suatu daerah menjadi baik untuk daerah lain, maka dari itu etis pada tiap-tiap daerah dan wilayah terkadang tidak sama. Namun, pada beberapa bidang, seperti akuntansi salah satunya, diperlukan standar tentang etika untuk mengatur profesionalisme para akuntan dalam berhubungan dengan sesama akuntan, klien maupun masyarakat yakni dengan adanya standar profesi yang dikeluarkan oleh Ikatan Akuntan Indonesia (IAI) (Sari, Zuhdi dan Herawati, 2012).

Perkembangan bisnis yang diikuti oleh berkembangnya berbagai keinginan para pemegang kepentingan mulai mendorong beberapa pelaku yang bekerja dibidang akuntansi untuk melakukan hal-hal yang kurang sesuai dengan etika akuntan yang berlaku. Munculnya kasus-kasus yang melibatkan profesi akuntan dalam beberapa tahun tentunya telah mencoreng kredibilitas dari profesi akuntansi. Menurut Stonciuviene dan Naujokaitiene (2013) munculnya perilaku tidak etis diakibatkan kurangnya pemahaman tentang norma etika dan adanya salah interpretasi terhadap perilaku etis.

Lantas, siapa yang bertanggung jawab atas perbuatan tidak etis akuntan ini? Tentu saja, tiap-tiap perilaku etis atau tidak yang dilakukan para akuntan bergantung dari diri mereka sendiri. Diri akuntan lah yang memutuskan apakah akan melakukan perbuatan etis atau melanggarnya. Namun demikian, ternyata dengan dimasukkannya pendidikan tentang kesadaran etis dalam ketrampilan akuntansi dapat membawa dampak panjang yang positif terutama dalam konteks bisnis yang membutuhkan pelaporan yang relevan (Graham, 2012). Etika memegang peran penting dalam akuntansi untuk memastikan efisiensi, integritas, akurasi, kerahasiaan, dan penyajian informasi keuangan yang akurat untuk setiap perusahaan (Gamage dan Rahman, 2020).

Temuan atas perilaku tidak etis yang dilakukan para akuntan memberikan penekanan lebih terhadap pendidikan etika selama pembelajaran pada program akuntansi (West, 2016). Lebih lanjut lagi, salah satu hal yang mempengaruhi perilaku etis dari seseorang merupakan lingkungan, tak terkecuali lingkungan pendidikan (Sari, Zuhdi dan Herawati, 2012). Oleh karena itu, hadirnya mata kuliah yang mengajarkan tentang bagaimana akuntan berperilaku secara etis sesuai dengan peraturan yang berlaku sangat dibutuhkan, harapannya adalah untuk mencetak generasi akuntan baru yang beretika. Adanya pemberian materi tentang prinsip-prinsip etika akuntansi diharapkan dapat membuat calon akuntan sadar bahwa praktik kecurangan akuntansi yang selama ini terjadi merupakan tindakan yang tidak dibenarkan atau tidak etis, dan diharapkan mereka bisa menyadari bahwa praktik kecurangan tersebut bisa dihentikan dengan memiliki kesadaran diri sendiri dan menanamkan prinsip etis. Pendidikan etika akuntansi membantu calon akuntan untuk mengenali masalah moral, mendukung untuk berperilaku etis serta meningkatkan kemampauan untuk menangani konflik etis profesi (Calivurt, 2008)

Mahasiswa yang belum menemui dunia kerja cenderung lebih memahami etika secara teoritis daripada para akuntan yang telah memasuki dunia kerja (Fiolleau dan Kaplan, 2016). Pendapat ini tentu masuk akal karena nyatanya situasi yang dihadapi saat terjun ke dalam dunia akuntansi secara nyata seringnya membuat para akuntan menghadapi masalah dilema etis, antara menaati standar etika yang berlaku atau menaati permintaan atasan yang melawan standar etika akuntan. Realita dalam dunia kerja yang ternyata tidak semudah dari teori tentang perilaku etis yang diajarkan selama menempuh perkuliahan membuat banyak para akuntan terutama akuntan yang baru saja memasuki dunia kerja menjadi bimbang. Lika-liku dunia kerja menjadi sering memaksa para profesi akuntan untuk menyimpang dari semua teori etis yang dipelajarinya. Maka, dibutuhkan juga upaya dari sebuah organisasi untuk memastikan bahwa implementasi etika profesional akuntansi telah diterapkan dengan baik, agar akuntan tidak membenarkan berbagai alasan atas perilaku non etisnya (Shairf, Junaid dan Malik, 2020).

Penelitian Hidayat \& Anastasyah (2017) meneliti tentang Perbedaan persepsi tentang etika bisnis pada mahasiswa yang belum dan sudah mempelajari mata kuliah etika bisnis pada prodi akuntasi di perguruan tinggi Kota Batam menyatakan bahwa terdapat perbedaan persepsi antara mahasiswa yang belum dan telah mempelajari mata kuliah etika bisnis. Selanjutnya, dari penelitian yang dilakukan Silanont (2012) mengungkapkan bahwa pelatihan etika ditempat kerja memberikan dampak terhadap 
karyawannya sehingga berperilaku lebih etis. Penelitian tentang pengaruh pendidikan etis juga diteliti oleh Al-Shaiks et al., (2012) dimana hasil penelitiannya menyatakan bahwa hadirnya pendidikan etika selama perkuliahan membuat perempuan dan laki-laki yang pada awalnya memiliki pandang yang berbeda terhadap etika bisnis menjadi memiliki pandangan yang sama.

Selanjutnya, dari penelitian yang telah dilakukan oleh Mulia (2012) yang berjudul mengungkap pemahaman tentang akuntansi dari kecerdasan emosional, spiritual dan sosial mahasiswa, mengungkapkan bahwa ternyata berbagai kecerdasan yang dimiliki mahasiswa akuntansi diakibatkan oleh berbagai karakter yang ada (pendidik maupun karakter mahasiswa sendiri) dan karena system yang telah mengakar pada pendidikan akuntansi saat ini. Penelitian yang dilakukan oleh Sari Zuhdi, \& Herawati (2012) tentang tafsir perilaku etis menurut mahasiswa akuntansi berbasis gender menunjukkan bahwa penafsiran perilaku etis oleh mahasiswa maupun mahasiswi ternyata masih serupa, hanya saja penafsiran perilaku etis yang diungkapkan mahasiswi akuntansi sedikit lebih baik dan lebih mendalam. Sedangkan penelitian yang dilakukan oleh Novita (2012) yang berjudul menguak persepsi etika mahasiswa akuntansi mengungkapkan bahwa mahasiswa akuntansi memiliki pemahaman etis yang lebih tinggi dibanding mahasiswa non-akuntansi, dan tidak terdapat pebedaan antara persepsi etika menurut mahasiswa dan mahasiswi.

Pada beberapa penelitian terdahulu, belum ditemukan penelitian yang meneliti tentang persepsi etis para fresh graduate akuntansi. Sehingga pada penelitian ini, para fresh graduate akuntan digunakan sebagai objek wawancara untuk menggali lebih lanjut lagi apa arti perilaku etis menurut mereka, serta mengetahui seberapa pentingkah etika dalam dunia kerja. Pendapat para fresh graduate akuntansi ini tentu akan menarik mengingat mereka yang baru saja menempuh perkuliahan akuntansi yang bermuatan pendidikan etika akan mengungkapkan seberapa pentingnya etika dalam dunia kerja, apakah pendapat mereka sejalan dengan teori etika yang selama ini dipelajarinya atau bahkan ternyata etika tidak terlalu digubris pada praktiknya. Para narasumber pada penelitian ini yakni fresh graduate yang merupakan lulusan jurusan akuntansi dari Politeknik Negeri Malang pada tahun 2019 yang telah bekerja pada sebuah organisasi pada posisi auditor, akuntan atau seputar keuangan lainnya, baik pada perusahaan swasta, BUMN, maupun yayasan. Oleh sebab itu, penelitian ini bertujuan untuk mengetahui bagaimana arti perilaku etis menurut para fresh graduate akuntansi.

Penelitian ini diharapkan dapat memberi masukan pada dunia pendidikan sebagai evaluasi atas pendidikan etika akuntansi yang selama ini diberikan pada mahasiswa akuntansi, dan untuk mengembangkan cara untuk menguatkan penanaman atas pentingnya etika akuntansi pada tahun-tahun yang akan datang. Penelitian ini juga diharapkan dapat bermanfaat bagi para akuntan yang telah bekerja yakni untuk refleksi tentang pentingnya perilaku etis dalam praktik akuntansi. Selain itu, bagi para pemakai (perusahaan, yayasan atau instansi dan lain lain) diharapkan mampu memberi dukungan lebih dan tidak memojokkan akuntan agar para akuntan selalu bisa menegakkan etika profesi di dalam praktiknya.

Perilaku adalah perwujudan seseorang ketika berinteraksi dengan lingkungan (Nurlaela, 2016). Perilaku menurut Notoatmojo (2010) adalah hasil dari berbagai pengalaman dan interaksi antara manusia dengan lingkungan yang diwujudkan dalam berbagai bentuk seperti sikap, tindakan ataupun pengetahuan. Selain itu, perilaku adalah respon individu atas stimulus dari luar maupun internal dirinya. Berdasar paparan definisi perilaku diatas, perilaku bisa diartikan sebagai tanggapan seseorang dalam menanggapi lingkungannya. Menurut Utami (2010), perilaku menjadi faktor yang sangat berpengaruh setelah faktor lingkungan, terhadap kesehatan individu ataupun kelompok. Perilaku dapat dipelajari dari kebiasaan, pengetahuan dan penggunaan model (Priyoto, 2014)

Etika dalam kamus besar bahasa Indonesia online merupakan sebuah ilmu yang mempelajari baik dan buruk serta mempelajari hak dan kewajiban moral atau akhlak dan etis merupaka sesuatu yang berhubungan dengan etika atau perilaku yang sesuai dengan yang disepakati secara umum. Sedangkan menurut kamus oxford, etika bisa diartikan sebagai prinsip moral yang mengatur atau mempengaruhi perilaku seseorang dan etis merupakan seuatu yang bermoral atau dapat diterima. Etika merupakan pedoman prinsip moral untuk perilaku seseorang untuk menentukan arah dalam pengambilan keputusan (Bishop, 2013). Sesuai dengan pengertian etika menurut KBBI diatas, etika menjadi penting karena dapat dijadikan patokan tentang apa yang salah dan apa yang benar dan dapat digunakan dalam mengambil keputusan.

Menurut Rosyida (2017), perilaku etis adalah kecenderungan pribadi atau kerakter seseorang yang bukan merupakan hasil dari pembelajaran. Perilaku etis yakni serangkaian norma yang berlaku dan diterima oleh masyarakat sekitar atas berbagai 
tindakan yang dianggap memiliki kebermanfaatan ataupun tidak (Putri, 2018). Perilaku etis juga diartikan dengan menunjukkan berbagai perlakuan tindakan seseorang ketika menjalankan tanggung jawabnya agar sesuai dengan nilai yang berlaku. Melaksanan perilaku yang sesuai denga etika yang berlaku tentu saja tidak mudah, banyak tantangan dan halangan yang membuat etika sulit atau bahkan tidak ditegakkan.

Etika menjadi sebuah pedoman yang digunakan sesorang dalam bertindak dan bersikap tak terkecuali pada sebuah profesi. Tiap tiap profesi pasti memiliki sebuah pedoman yang dijadikan acuan untuk bertindak guna menjaga kehormatan sebuah profesi tak terkecuali profesi akuntansi, yakni etika akuntansi. Etika akuntansi mengarah pada prinsip-prinsip tentang pedoman para profesi akuntan dalam bertindak.

Etika profesional terdiri dari perilaku para profesional yang telah dirancang dengan matang guna sebuah tujuan yang ideal. Etika profesional menjadi pertimbangan dan pedoman bagi para profesional yang tergabung, dalam bertindak atas keprofesionalannya. Etika profesional pada individu ditunjukkan dengan ciri berikut (Greenstone, 2018), individu akan menyadari aturan yang berlaku atas nilai yang berlaku, individu mau untuk berbicara dengan semua lapisan dalam organisasi dan setiap interaksi pada organisasi selalu mempertimbangkan etika yang berlaku.

Pada dunia bisnis, etika dalam akuntansi menjadi masalah yang sering menjadi objek kesalah pahaman. Maka diperlukan pemahaman terhadap prinsip prinsip etika akuntansi agar hal itu tidak terjadi. Prinsipprinsip etika profesi akuntansi yang berlaku di Indonesia disahkan oleh Ikatan Akuntan Indonesia (IAI). Profesi akuntan memiliki lima prinsip dasar menurut IAI 2020, diantaranya adalah Integritas, Obyektivitas, Kompetensi dan Kehati-hatian Profesional, Kerahasiaan, dan Perilaku Profesional.

Integritas merupakan sikap jujur pada berbagai hubungan dalam bisnis atau ranah profesional. Inegritas mengharuskan para akuntan terus terang terhadap keadaan yang sebenarnya dan tidak boleh ditutup tutupi. Integritas dapat digambarkan dengan bisa dipercaya dan diandalkannya seseorang (Redjeki \& Ferdiansyah, 2013). Integritas yang dimilliki profesi akuntan dapat dilihat dengan satunya perbuatan dan kata yang telah diucapkan, bukan memikirkan kepentingannya sendiri.

Objektivitas yakni sebuah sikap yang tidak mengedepankan kepentingannya, sehingga informasi yang dilaporkan tidak bias dan tidak dalam tekanan pihak manapun. Para profesi akuntan juga dilarang untuk bekerja dalam kegiatan profesionalnya apabila sedang memiliki hubungan bisnis atau apapun yang dapat mempengaruhi penilaiannya dalam bekerja. Objektif yakni dapat membuktikan bahwa setiap tindakannya sesuai pedoman yang berlaku serta tidak terdapat benturan kepentingan (Sari, 2011) jurnal Ananda pratiwi

Kompetensi dan kehati hatian profesional merupakan sikap para akuntan untuk memastikan bahwa jasa yang diberikannya kompeten dan sesuai dengan perkembangan yang teknik dan standar yang sedang berlaku, untuk itu akuntan harus selalu meningkatkan pengetahuan dan profesionalitasnya. Akuntan harus bersungguh sungguh dalam menjalankan pekerjaannya sesuai dengan standar akuntansi yang berlaku. Kesalahan boleh saja ditolerir namun bukan kesalahn yang disengaja.

Kerahasiaan adalah suatu sikap untuk menjaga informasi rekan bisnis atau profesional terhadap siapapun, kecuali terdapat hak dan kewajiban untuk mengungkapnya. Akuntan harus selalu berusaha untuk tidak mengungkap kerahasiaan klien kepada siapun termasuk keluarga. Kerahasiaan yang harus dijaga klien harus tetap dijaga walaupun hubungan kerjasama antara akuntan dan klien ini telah berkahir.

Perilaku profesional yakni akuntan wajib patuh terhadap aturan dan hokum yang berlaku demi menjaga kepercayaan publik terhadap profesi akuntan. namun lebih lanjut, menurut Busila (2014) kode perilaku yang ada sama sekali tidak dapat menjamin bahwa seseorang itu akan menjadi berperilaku etis, karna hanya kesadaran dari dirilah yang dapat menjadikan seseorang menjadi beretika.

\section{METODE PENELITIAN}

Penelitian kualitatif dengan Paradigma interpretatif digunakan dalam penelitian ini, dimana penelitian kualitatif menurut Mulyadi (2011) adalah penelitian dengan mendeskripiskan penelitian dalam kata atau Bahasa dengan metode ilmiah, penelitian ini bertujuan untuk mengetahui dan memahami atas kejadian yang terjadi pada subjek penelitian seperti persepsi, tindakan, perilaku. Sedangkan Paradigma interpretatif adalah Paradigma yang memberi penekanan pada bahasa, interpretasi dan pemahaman, jadi pengetahuan pada Paradigma interpretatif tidak digunakan sebagai penjelas dan pembuat prediksi namun digunakan untuk memahami. Paradigma interpretatif mengasumsikan bahwa kenyataan sosial yang terjadi dibentuk dari berbagai pengalaman subyektif-obyektif masing masing indvidu (Mulia, 2012). 
Penelitian dilakukan dengan mewawancarai para fresh graduate akuntansi. Wawancara yang dilakukan termasuk wawancara semi terstruktur dan tidak terlalu formal. Wawancara merupakan percakapan yang terarah yang dapat dilakukan oleh dua orang atau lebih. Wawancara semi terstruktur adalah wawancara yang dilaksanakan dengan lebih bebas dibanding wawancara terstruktur (Sugiono, 2012, hal. 233). Pada jenis wawancara ini, peneliti diharap dapat dengan teliti mencatat setiap yang dijawab oleh narasumber atau informan. Wawancara semi terstruktur bertujuan untuk mengulas permasalahan denga lebih terbuka sehingga narasumber atau informan dalam menuangkan berbagai ide, gagasan atau pendapat yang dimilikinya. Informan penelitian ini yaitu empat orang lulusan fresh graduate akuntansi Politeknik Negeri Malang yang telah bekerja pada bidang akuntansi, finance atau sejenisnya yang masih berhubungan dengan akuntansi. Wawancara dilakukan dengan santai namun peneliti tetap memfokuskan pada daftar pertanyaan-pertanyaan utama dengan melalui via telepon. Pada masing masing informan, wawancara dilakukan rata-rata selama 45-60 menit. Narasumber atau informan pertama yakni Fay yang bekerja pada kantor akuntan publik di Jakarta, narasumber kedua yakni Lala yang merupakan pegawai dibidang akuntansi pada perusahaan rokok yang terkenal di Indonesia, selanjutnya informan ketiga yaitu Rama yang merupakan pegawai pada bagian payroll di perusahaan manufaktur elektronik, informan keempat yaitu Vanda yang bekerja pada sebuah pabrik ekspoimpor perkebunan di Sidoarjo. Masing masing nama telah disamarkan oleh peneliti.

\section{HASIL DAN PEMBAHASAN}

Secara konsep, etika merupakan sebuah falsafah tentang moral dan menjadi sebuah arah dari segi budaya, susila serta agama dalam tingkah laku sehari hari (Sari \& Herawati, 2012). Perilaku etis yang terdapat dalam individu dapat tercermin dalam setiap aspek kehidupan. Tanggapan seseorang tentang pentingnya Etika itu sangat beragam, tergantung oleh individu, lingkungan sekitar, kelompok atau budaya organisasi. Menurut hasil wawancara pada keempat informan yang dijadikan objek wawancara, tiga diantaranya sepakat bahwa etika secara konsep dan praktik itu tidak jauh berbeda. Ketiga informan berpendapat yang pada intinya menyatakan bahwa etika secara konsep dan perilaku itu sama, etika itu adalah panduan untuk bertindak dan berperilaku di dalam kehidupan sehari-hari kita tak terkecuali profesi akuntansi. Berikut salah satu pendapat informan Rama dalam mengungkapkan pentingnya akuntansi pada dunia kerja.

"Kalau dibilang ngaruh jawabnya iya. Karena apa? kita kerja di kantor atau di manapun nggak mungkin jalan sendiri pasti selalu berkaitan dengan departemen lainnya. Nah kalau kita mau meminta bantuan dari pihak lain secara general kan harus sopan nggak boleh grusa-grusu, komunikasi harus jelas, mau menanyakan sesuatu ada baiknya kita pahami dulu tentang apa yang mau ditanyakan secara spesifik kemudian mempersiapkan harus ngobrol seperti apa, initnya harus bisa memposisikan diri kita agar orang lain tidak sampai tersinggung, jadi komunikasi harus lebih halus. Jadi, etika kan sebenarnya berkaitan dengan hati nurani, kalau aku kayak gitu, benar gak ya? Intinya kita harus bisa mencapai tujuan kita tanpa mengganggu orang lain"

Pendapat diatas mempertegas pernyataan bahwa, etika tidak bisa ditinggalkan, dalam hal ini pada bidang akuntansi terutama. Bekerja sebagai akuntan jelas tidak bisa bekerja sendiri, butuh koordinasi dan kerjasama dengan divisi atau departemen lain untuk mengerjakan berbagai laporan akuntansi. Maka sebab itu, sebagai akuntan diharapkan selalu dapat mempertimbangkan etika yang berlaku dalam bertindak. Ketika akuntan membutuhkan sesuatu dari departemen atau bagian lain, akuntan harus bertindak berdasar perilaku etis, sehingga kerjasama atau hubungan dengan departemen atau bagian lain tersebut terjaga dengan baik. Tentu saja terjalinnya komunikasi yang baik ini juga akan memberikan dampak positif bagi akuntan sendiri. Departemen lain akan mengupayakan mengumpulkan data data yang diperlukan untuk pekerjaan akuntansi dengan lebih serius dan tanpa perlu ditagih terus menerus apabila akuntan dan departemen lain ini memiliki hubungan yang baik. Departemen lain akan cenderung mau berterus terang atas peristiwa atau transaksi tertentu apabila akuntan butuh untuk mencari informasi guna evaluasi.

Pendapat berbeda diutarakan oleh Vanda, menurutnya etika secara konsep dan penerapanya itu terkadang masih banyak yang berbeda. Etika trekadang bukan lagi menjadi pedoman atau acuan, namun ada hal lain yang bisa "menggantikan" posisi etika dalam profesi akuntansi.

"Konsep etika sendiri dengan prakteknya itu menurutku ya ini, praktik dengan konsep bertingkah laku yang baik dari budaya, suku, agama itu sering- 
sering berbeda gitu. Jadi ada suatu kepentingan kepentingan pribadi atau golongan tertentu yang akhirnya menghalalkan segala cara untuk kepentingan tersebut, jadi kan dia melanggar etika tersebut. Pasti akan ada suatu apa ya suatu konflik kepentingan yang mengakibatkan dia itu melanggar etika, praktek etika itu sering melanggar etika yang berlaku. Atau lebih jelasnya lagi gini, secara konsep etika kan menentukan apa yang baik dan apa yang buruk, tapi ternyata sejauh aku kerja ini, aku mulai memahami bahwa terkadang kita bertindak itu sesuai dengan perintah atasan buka sesuai etika yang berlaku, jadi ga peduli itu baik atau buruk tapi kalo atasan meminta melakukan tugas tertentu ya harus tak lakukan karena aku masih anak baru dan belum punya wewenang apa apa, jadi ya manut manut aja hehe.."

Seorang atasan dalam pekerjaan memang menjadi salah satu hal yang paling penting dalam penegakan etika akuntansi. Pada pendapat dari Vanda tersebut, masih terlihat bahwa menjadi seorang fresh graduate akuntan dan kemudian bekerja pada bidang akuntansi menjadi cukup sulit apabila ingin menjadi orang yang berperilaku etis sesuai prinsip yang berlaku. Tekanan pihak-pihak yang tidak menjalankan prinsip etika dalam profesi akuntan memberikan imbas buruk terhadap orang-orang disekitarnya. Tentu saja keadaan ini menjadika profesi akuntan menghadapi sesuatu yang dilema, antara mematuhi prinsip etika atau mematuhi atasan.

Penggalakan aturan sesuai dengan undang-undang yang berlaku dapat menjadi salah satu alternatif untuk mengurangi perilaku tidak etis. Selain itu metode whistle blowing juga dapat menjadi alternative lain yang juga mampu membantu para akuntan baru untuk mengungkapkan kondisi yang terjadi sebenarnya kepada pihak yang berwenang, sehingga bentuk tindakan tidak etis yang dilakukan pihak tertentu menjadi berkurang atau bahkan hilang. Menurut Bowen et al (2010) whistle blowing ini mampu meningkatkan governance suatu perusahaan.

Lebih lanjut lagi, pertanyaan mengenai kapan etika itu harus dimunculkan dijawab dengan pendapat yang hampir mirip oleh keempat informan. Mereka sepakat bahwa etika tentu saja wajib muncul dalam segala aspek kehidupan yang dijalani. Mereka tak menampik bahwa etika memang sangat diperlukan dalam berinteraksi dengan lingkungan. Seperti pada wawancara yang telah dilakukan, kali ini Fay berpendapat bahwa,
"Ya pastinya dalam setiap aspek kehidupan harus ada etika sih ya, karena itu pedoman agar individu dapat berperilaku dengan baik, tiap kegiatan apapun harus melibatkan etika, cuman emang itu balik lagi ke individu masing-masing dan juga kondisi sosial, budaya dan lingkungan, jadi setiap kegiatan apapun kita ya harus melibatkan etika, gitu menuruku"

Sikap individu dapat menentukan arah warna atau corak pada individu dalam bertingkah (Hedri \& Suyanto, 2018). Individu yang bersikap ramah, dan selalu menghargai orang lain maka tingkah lakunya pun akan cenderung lebih disenangi oleh orang lain dalam bergaul daripada individu yang bersikap kasar. Hal ini karena individu yang memiliki sikap kasar tersebut cenderung akan sering melakukan hal hal yang dianggap buruk dan membuat orang lain merasa tidak nyaman, dimana hal itu tidak etis. Etika menjadi salah satu alat untuk menciptakan ketenangan dan kenyamanan, baik untuk individu maupun lingkungan sekitar. Adanya etika dapat membuat kehidupan menjadi lebih teratur dan terarah. Tentunya, penegakan etika sendiri seharusnya muncul dari kesadaran diri tentang bagaimana etika yang benar dan yang harus dijalankan (Sari, Zuhdi \& Herawati, 2012)

Pertanyaan selanjutnya yang membahas atas skandal kasus akuntansi yang mulai marak muncul sejak terbongkarnya kasus Enron yang melibatkan KAP Arthur Andersen, dan tidak lama kemudian ternyata juga muncul kasus yang melibatkan profesi akuntansi seperti pada perusahaan Tyco, Global Crossing, WorldCom dan lain lain, sehingga kejadian tersebut semakin mencoreng nama baik profesi akuntan. Saat ini, etika merupakan isu yang relevan bagi profesi akuntan (Febriansyah et al, 2016) akibat maraknya skandal-skandal akuntansi tersebut semakin menambah tantangan lebih kepada para akuntan untuk membangkitkan kepercayaan publik lagi terhadap profesi akuntan. Mematuhi prinsip etika profesi akuntan dengan bersungguh-sungguh bisa menjadi salah satu jalan untuk mengambil perhatian publik untuk membangun kepercayaan terhadap profesi akuntan. Menanggapi pertanyaan tentang maraknya kasus akuntansi tersebut, salah seorang informan yaitu Lala berpendapat,

"Yo karena gini lo, kantor akuntan publik pasti cari klien ga si? Apalagi kan rata rata yang bikin laporan keuangan itu sebenere malah akuntan publiknya kan? Jadi ya menurutku itu pasti mereka ya emang sekongkol lah, ga mungkin lah kalo ga ngerti. Di perusahaan ku sendiri kalo lagi audit, pasti auditor 
publiknya itu nemuin apa ya, bukan kecurangan sih tapi semacam kesalahan gitu, jadi auditor publik e Tanya, lo ini jurnal nya kok gini? Sebenernya ga boleh ini, nah ketauhan kan itu. Jadi intinya, kalo sampe ada skandal akuntansi kaya Enron itu ya pasti emang disengaja itu, mereka (akuntan publik) kan kaya gitu dibayar dan ga kehilangan klien."

Pendapat lain dari Rama mengatakan bahwa,

"Berarti etika akuntan e lemah, dan satu lagi mungkin juga kondisi di lapangan sangat mendukung adanya kasus-kasus negatif mengenai skandal-skandal akuntansi iku ya. Misal yo dalam KAP, observasi keluar ke PT. A satu tim 4 orang, trus 3 orang sudah bisa di "nego" sama perusahaan yang jadi klien untuk memberikan status WTP atau yangg baik-baik lah pokoknya, lha lek 1 orang ga setuju kan sebenere yang masalah ada di 3 orang yang setuju kan. Mereka dari perusahaan yang sama, dapat ilmu-ilmu dari perusahaan yg sama juga (sebagai auditor dilapangan harus ini ini, tidak boleh ini ini), dapat ilmu etika juga dari waktu dulu sekolah. Mungkin 3 orang tadi yang mau sekongkol sama perusahaan perlu uang imbalan e karena kebutuhan ini itu. Tapi itu tadi ya kembali ke niat sama kebiasaan dan hati nurani nya main apa ngga. Harusnya mereka mikir kalo aku mau gini pantas gak ya? Kan sebagai akuntan kan ya harus punya prinsip-prinsip integritas dan sebagainya gitu kan, nah itu juga harus dipegang sih biar skandalskandal itu ga sampai terjadi lagi"

Seorang akuntan sangat berpotensi akan menemui kondisi-kondisi dilema etis antara mengutamakan kepentingan sendiri beserta keuntungan materi yang akan diperoleh (Caglio \& Cameran, 2015). Dua pendapat dari informan mengatakan bahwa kasus akuntansi yang terjadi itu memang sebuah kesengajaan, mungkin dengan motif kebutuhan kantor publik atas klien atau kebutuhan para auditor atas uang atau kepentingan lainnya. Selain itu, menurut Sari dan Ruhiyat (2017) tekanan dari atasan ataupun klien meberi dampak negative dan signifikan terhadap hasil opini audit, tekanan tersebut akan cenderung membuat seorang auditor bertindak tidak etis atau melakukan penyimpangan, dan auditor akan cenderung memberikan pendapat audit yang kurang tepat apabila dibandingkan dengan auditor lain yang berpegang pada standar profesional yang berlaku dan tidak menerima tekanan dari atasan ataupun klien.

Akuntan memiliki kewajiban pada organisasi atau perusahaan, profesi, terhadap publik dan juga terhadap diri mereka sendiri untuk menegakkan standar tertinggi dalam perilaku etis. Mereka memiliki kewajiban agar kompeten dan memelihara kepercayaan, integritas, dan objektivitas. Menurut Mutmainah dan Asy'ari (2004) keberhasilan akuntan dipengaruhi oleh nilai dan etika. Akuntan yang teguh memeang prinsip akan dapat mempertanggungjawabkan pekerjaan yang telah dilakukan. Apalagi para pemakai laporan akuntansi menggunakan laporan tersebut untuk dijadikan sebagai dasar pembuatan keputusan, sehingga ketika ditemukan ketidak benaran akuntansi, maka bisnis dan citra kantor audit juga akan runtuh. Investor tidak akan percaya lagi terhadap segala sesuatu informasi yang dihasilkan karena kedua pihak tersebut dianggap memberi ketidakpastian dan perasaan tidak aman.

Membahas mengenai kecurangan-kecurangan yang sering terjadi akhir-akhir ini lantas memunculkan pertanyaan tentang seberapa penting hadirnya etika dalam praktik akuntansi yang ada saat ini, hasil wawancara yang telah dilakukan dengan keempat para informan, mereka rata-rata berpendapat bahwa tentu saja sebagai seorang akuntan Etika itu sangat penting, karena Bagaimana kita bisa menjalankan profesi atau pekerjaan kita apabila kita tidak memiliki dan menaati prinsip etika yang ada. Contoh saja seperti kerahasiaan yang diungkapkan oleh informan Rama yang berpendapat bahwa,

"Penting banget lah. Karena misal kalau akuntan gak bisa jaga kerahasiaan nih misalnya, hmm kaya di kerjaanku sekarang, aku kan ya pegang penggajian, untuk si A status $\mathrm{S}$ gaji sekian dapet tunjangan perumahan, skil, bahasa, si B status $\mathrm{K}$ gaji sekian dapet tunjangan profesi dan bahasa saja misalnya. Oke mungkin dilapangan orang sudah sama-sama tau kalo Si A tau si B dapet apa aja dan sebaliknya. tapi sebagai akuntan kan kita harus menjaga data-data yang menimbulkan friksi atau ketegangan ya karena sifatnya konfidensial, jadi misal kalo kita mau proses penggajian Bulan april misalnya data yang udah kita dapet dari HR tadi, harus di simpan dan jangan sampai ada yang tahu, misal pengen istirahat ya jangan ditaruh meja dan terpampang gitu, nanti kan berpotensi dibaca orang, jadi taruh di map, taruh laci atau dimana gitu yang tersembunyi"

Sedangkan menurut Vanda,

"Sangat penting, ngga cuman soal akuntan public aja ya, semua akuntan harus kredibel dan punya integritas, gaboleh terpengaruh dengan kepentingan ini itu, nilai kaya gini dasarnya apa gitu, akuntan itu harus bisa ngatur buka diatur, jadi akuntan harus punya interitas, apalagi kalo diperusahaan ku kerja ini sering banget masing-masing depaertemen punya kemauan ini-itu 
yang beda beda, makanya jadi akuntan itu harus paham banget sama ilmu akuntansi biar tindakannya itu sesuai dasar akuntansi”

Faya juga berpendapat bahwa,

"Sangat penting sih menurutku, karena Coba bayangkan kalau misalnya kita tidak memiliki prinsip kerahasiaan, bagaimana kita bisa dipercaya kalau misalnya kita nggak punya sifat kerahasiaan, kita tidak bisa menjaga sesuatu, kita tidak berintegritas juga. Terus bagaimana menyelesaikan pekerjaan kalau kita tidak punya kompetensi sama keprofesionalan trus kehati-hatian, bagaimana orang yang bisa percaya bahwa pekerjaan yang kita lakukan itu benar-benar sudah sesuai atau tidak kalo kita gak menerapkan etika akuntansi"

Menjadi seorang akuntan secara tidak langsung juga telah menjadi seorang profesional. Menjadi seorang profesionalitas membuat individu harus mampu menghadapi berbagai tuntutan dan tantangan yang tidak mudah, oleh karena itu seorang profesional sering dianggap sebagai sekumpulan individu yang punya tolak ukur diatas rata-rata (Mispiyanti, 2016). Dibutuhkan suatu standar kode etik yang tinggi agar profesional menjadi berkualitas. Namun, tidak cukup dengan munculnya kode etik saja agar profesional menjadi orang yang berkualitas, kesadaran akan pentingnya implementasi kode etik tersebutlah yang sangat menentukan apakah profesional ini berkualitas atau tidak. Para profesional khususnya dibidang akuntansi yang tidak pernah sadar akan sebuah etika dalam menjalankan pekerjaannya dapat membuat sebuah citra profesinya menjadi terdegradasi, lunturnya etika membuat nama profesional mereka menjadi hilang dan menjadi sebuah profesi biasa sehingga hilanglah kepercayaan publik kepada para profesional tersebut.

Kesadaran akan penerapan etika akuntansi dalam praktiknya menurut keempat para fresh graduate akuntansi tersebut sedikit memberi harapan kepada publik, bahwa nyatanya, masih ada akuntan-akuntan muda yang sadar akan hadirnya etika akuntansi ini kedalam praktik akuntansi. Lebih lanjut, berkaitan dengan pembicaraan mengenai etika ketika memasuki dunia kerja atau praktiknya memunculkan pula sebuah pertanyaan tentang sebenarnya apakah pendidikan mengenai etika dalam perkuliahan, berpengaruh terhadap praktik akuntansi mereka saat ini, Vanda mengatakan bahwa,

"Hmm apaya, aku gak yakin sih, hehe apa akunya yang ga ngerasain ya, tapi gini, kalo kerja kan kita mengutamakan profesional, jujur dan integritas, jadi yang ada lah ngaruhnya dikit, tapi sekarang aku kan lagi di posisi finance yang fresh graduate, jadi kadang masih sering diatur atur sama akuntansinya, meskipun kadang aku sendiri heran, lo kok gini bukaannya seharusnya ga gini ya, tapi kalo dipikir lagi sih, ya ada kok efek dari perkuliahan soalnya kan dalam bekerja kalo ga jujur, ga profesional kan ngaruh ke manajemen missal nanti laporan yang jadi kerjaan kita jadi molor gitu kan"

Sedangkan menurut Lala, etika yang diajarkan dalam perkuliahan berpengaruh sebagai dasar dalam penegakan etika di perusahannya bekerja,

"Ngaruh, sebagai dasar aja, karena kan diperusahaan sudah ada SOP tersendiri, jadi ya pengetahuan kita tentang etika akuntansi dari perkuliahan bisa dijadikan dasar untuk mematuhi SOP itu"

Sedikit berbeda dengan pendapat Lala dan Vanda, Rama memberikan presentase yang cukup besar atas peran pendidikan etika akuntansi selama perkuliahan,

"Etika akuntansinya ya, kalo pake skala sekitar 70\% berpengaruh sih, dan etika yang kita pegang adalah sebagai anak baru kita pasti bener-bener hati-hati dan menjaga kerahasiaan tapi disisi lain kalo menurutku masih belum bisa profesional karena kan masih peralihan kan dari fresh gradute ke new member staff"

Sedangkan Faya berpendapat bahwa baginya etika yang didapat selama perkuliahan hanya sebatas prinsip etika akuntansi saja.

"Waduh, ngaruh gak ya? aku Cuma tau ya ada prinsip etika waktu kuliah etika akuntansi, hehe, masalahnya aku ga terlalu paham waktu mata kuliah yang berhubungan dengan etika, aku nganggap mata kuliah itu Cuma konsep gitu, aku itu orangnya ga paham secara teori etika itu apa, apalagi kalo lebih dalam lagi, aku ga paham",

Berdasar pendapat para informan yang telah memasuki dunia kerja, pendidikan tentang etika yang didapat selama perkuliahan ternyata sedikit banyak berpengaruh terhadap dunia kerja mereka. Walaupun salah seorang informan diatas berpendapat bahwa etika masih belum bisa ditegakkan sepenuhnya dalam dunia kerjanya saat ini, karena statusnya yang masih fresh graduate masih akan terus memaksanya untuk tunduk pada atasan. Namun, setidaknya mereka telah memiliki dasar pengetahuan dan pemahaman akan perilaku etis. Etika dalam pendidikan berpengaruh terhadap persepsi etika mahasiswa (Hidayat \& 
Anastayah, 2017), hal ini dikarenakan pengetahuan dan pola pikir mereka terbentuk atas kurikulum yang telah dipelajarinya. Pendidikan etika mengajarkan apa yang baik dan buruk, apa yang benar dan salah, serta bagaimana cara nya mengambil keputusan tepat dengan banyak pertimbangan.

Pada masa yang akan datang, akan selalu dibutuhkan pendidikan yang berkualitas karena dibutuhkannya peningkatan sumber daya manusia yang lebih profesional. Hadirnya mata kuliah yang berkaitan dengan etika dalam dunia bisnis dapat memberi gambaran dan pelajaran para mahasiswa tentang bagaimana kondisi dunia kerja dan bagaimana cara mengatasi kecurangan-kecurangan yang terjadi. Hal ini dapat memberikan ketajaman perilaku etis dan pengetahuan akan etika kepada calon generasi akuntan. Walaupun nyatanya dalam dunia kerja, tidak semua masalah yang terjadi bisa dicari dalam buku etika yang dipelajari, namun setidaknya dengan penanaman perilaku etis kepada mahasiswa dapat menjadi dasar yang baik dalam menentukan penyelesaian masalah agar masih sesuai dengan etika yang ada.

Menurut Meilisia \& Ludigdo (2010) peran penting yang dimiliki oleh pendidikan akuntansi adalah mencetak generasi akuntan yang profesional dibidangnya. Output berupa akuntan yang profesional akan sangat berpengaruh terhadap praktik akuntansi dalam bekerja, sehingga lembaga pendidikan dalam hal ini pada bidang akuntansi, harus mengedepankan pendidikan yang etis dan bermoral. Walaupun mata kuliah tentang etika masih sering dianggap sebelah mata, namun penekanan dan penguatan pendidikan etika selama perkuliahan sangat dibutuhkan dan perlu ditingkatkan agar akuntan menjadi generasi yang profesional.

\section{KESIMPULAN}

Berdasar uraian diatas, dapat dilihat bagaimana arti penting perilaku etis dalam dunia kerja menurut fresh graduate akuntansi. Dimana rata-rata jawaban yang diperoleh pada penelitian ini yang berkaitan seputar etika yakni mengenai etika secara konsep dan praktiknya tidak jauh berbeda, walaupun ada seorang informan yang mengatakan bahwa seorang atasan dalam pekerjaan, dapat menjadi lebih ditaati daripada etika yang berlaku, namun hal tersebut bisa dicegah dengan memperketat aturan tempat kerja agar para atasan tidak semena-mena. Etika merupakan suatu hal yang harus muncul dalam setiap aspek kehidupan, karena etika merupakan sebuah pedoman tentang apa yang benar dan salah. Etika harus hadir dalam diri individu, karena sebaik apapun aturan atau standar yang ada tidak akan berjalan apabila individu tidak memiliki kesadaran diri. Etika menjadi penting dalam dunia kerja karena etika bisa dijadikan sebuah dasar untuk bertindak, memutuskan sesuatu ataupun dasar menaati peraturan yang ada. Lebih lagi, individu sebagai profesional akuntansi tidak akan bisa dipercaya untuk bekerja apabila dirinya tidak memiliki perilaku etis. Kemudian, sesuai dengan penelitian yang dilakukan oleh Hidayat \& Anasytasyah (2017), Silanont (201) dan Al- shaikh et al., (2012) pendidikan etika dapat sangat mempengaruhi persepsi dan perilaku etis para mahasiswa, dalam hal ini juga terlihat berpengaruh terhadap lulusan fresh graduate akuntansi. Penelitian ini terbatas pada informan yang sangat sedikit dan hanya berasal dari lulusan satu institusi pendidikan saja yaitu Politeknik Negeri Malang. Penelitian lebih lanjut diharapkan dapat memperluas informan untuk diwawancara guna mengetahui bagaimana tangggapan para fresh graduate akuntansi dari institusi pendidikan lain terhadap etika dalam penerapannya didunia kerja.

\section{Daftar Pustaka}

Al-shaikh, F. N., Elian, M. I., \& Tahat, L. H. (2012). Business Studentds Attitudes towards Business Ethics: Evidence from Kuwait. Journal

of International Conference on Business, Economics, and Behavioral Sciences.

Bishop, W. H. (2013). The role of ethics in 21st century organizations. Journal of Business Ethics, 118(3), 635- 637.

Bowen, R. M., Call, A. C., \& Rajgopal, S. (2010). Whistle-blowing: Target firm characteristics and economic consequences. Accounting Review, 85(4), 1239-1271. https://doi.org/10.2308/accr.2010.85.4.1239

Caliyurt, K. T. (2008). Chapter One Accounting Ethics Education: Is There A Difference Between Developed And Developing Countries? Globalization and Social Responsibility, 1.

Febriansyah, S., Deviyanti, D. R., Setiawati, L., Ekonomi, F., \& Mulawarman, U. (2016). Analisis perbedaan perilaku etis pelaku akuntansi berdasarkan karakteristik individu dalam etika penyusunan laporan keuangan. 1(1), 66-76.

Ferrell, O. C., Harrison, D. E., Ferrell, L., \& Hair, J. F. (2018). Business ethics, corporate social responsibility, and brand attitudes: An exploratory study. Journal of Business Research.

Fiolleau, K., \& Kaplan, S. (Accepted/In press). Recognizing Ethical Issues: An Examination of Practicing Industry Accountants and Accounting Students. Journal of Business Ethics, 1-18. https://doi.org/10.1007/s10551-016-3154-2

Furqani, H., Laldin, M., \& Mulyany, R. (2016). Good Finance: Integration of Ethics and Shariah in Islamic Finance. International Journal of Islamic Business Ethics, 1(2), 121. 
https://doi.org/10.30659/ijibe.1.2.121-130

Graham, A. (2012). The Teaching of Ethics in Undergraduate Accounting Programmes: The Students' Perspective. Accounting Education, 21(6), 599-613. doi:10.1080/09639284.2012.725638

Greenstone, A. F. 2018. Ethics and Public Integrity in Space Exploration. Acta Astronautica, 143, 322-326.

Hedri, N., \& Suyanto. (2018). Good corporate governance -. Wahana Islamika: Jurnal Studi Keislaman, 4(1), 127-149.

Hidayat, H., \& Anastasyah, D. (2017). Perbedaan Persepsi Tentang Etika Bisnis Pada Mahasiswa Yang Belum Dan Sudah Mempelajari Mata Kuliah Etika Bisnis Pada Prodi Akuntasi Di Perguruan Tinggi Kota Batam. JURNAL AKUNTANSI, EKONOMI Dan MANAJEMEN BISNIS, $\quad 5(2), \quad 204$ https://doi.org/10.30871/jaemb.v5i2.465

Meilisia, F., \& Ludigdo, U. (2010). Persepsi Mahasiswa Akuntansi Terhadap Etika Akuntan Pendidik Di Jurusan Akuntansi Fakultas Ekonomi Universitas Brawijaya. Jurn Akuntansi MultiParadigma, 1(2), 223-238. Https://Doi.Org/10.1017/CBO9781107415324.004

Mispiyanti, M. (2016). Peranan Etika Profesi Dalam Perilaku Akuntan. Fokus Bisnis: Media Pengkajian Manajemen Dan Akuntansi, 15(1), 24-37. https://doi.org/10.32639/fokusbisnis.v15i1.69

Mulia, A. S. (2012). Dari Kecerdasan Emosional, Spiritual. Jurnal Akuntansi MultiParadigma, 3(3), 441-454. jamal.ub.ac.id

Mulyadi, Muhammad. (2011) "Penelitian Kuantitatif dan Kualitatif Serta Pemikiran Dasar Menggabungkannya" Jurnal Studi Komunikasi dan Media Vol 15. No. 1, hlm 127 - 138

Nambukara-Gamage, B., \& Rahman, S. (2020). Ethics in Accounting Practices and Its Influence on Business Performance. PEOPLE: International Journal of Social Sciences, 6(1), 331-348. https://doi.org/10.20319/pijss.2020.61.331348

Notoatmodjo, Soekidjo. Ilmu Perilaku Kesehatan. Jakarta. Rineka Cipta. 2010

Novita, S. (2012). Menguak persepsi etika mahasiswa akuntansi. Jurnal Ekonomi Dan Keuangan, 14(80), 468-502.

Nurlaela, A. (2016). Peranan Lingkungan Sebagai Sumber Pembelajaran Geografi Dalam Menumbuhkan Sikap Dan Perilaku
Keruangan Peserta Didik. Jurnal Geografi Gea, 14(1), 40-48. https://doi.org/10.17509/gea.v14i1.3361

Yulia Ananda Putri. (2018). Pengaruh Contrual Of Self Terhadap Perilaku Etos Akuntan Minangkabau. Fakultas Ekonomi Universitas Negeri Padang, 6(1), 27.

Redjeki, D. P. S., \& Herdiansyah, J. (2013). Memahami Sebuah Konsep Integritas. Jurnal Pelopor Pendidikan STIE Semarang, 5(3), 1-14.

Rosyida, I. A. (2017). Perilaku Etis Dan Tidak Etis Oleh Akuntan Dalam Sebuah Organisasi. Ekonika: Jurnal Ekonomi Universitas Kadiri, 2(1), 23-39. https://doi.org/10.30737/ekonika.v2i1.16

Sari, R. S. N., Zuhdi, R., \& Herawati, N. (2012). Tafsir Perilaku Etis Menurut Mahasiswa Akuntansi Berbasis Gender. Jurnal Akuntansi MultiParadigma, 3(April). https://doi.org/10.18202/jamal.2012.04.7149

Sekaran, Uma. 2016.Research Method for Business A Skill Building Approach, 7th Edition. Salemba Empat. Jakarta

Shairf, I., Junaid, M., \& Malik, F. (2011). Major Causes of Breaching Accounting Ethics in Organizations : 9, 716-729.

Silanont, S. P. (2012). Business Ethics Perception of Thai Workforce: A Study of Age, Gender, Education, Management Experience and Ethics Training. School of Business and Technology of Webster University.

Sugiyono. 2012. Metode Penelitian Kuantitatif Kualitatif dan R\&D. Bandung:Alfabeta.

Stonciuviene, N., \& Naujokaitiene, J. (2013). Formation Of The Ethics Of Professional Accountants From A Moral Standpoint: Analysis Of Decisive Factors And Their Influnce. European Scientific Journal 1.

West, A. (2016). After Virtue and Accounting Ethics. Journal of Business Ethics, 148(1), 21-36. doi:10.1007/s10551-016-3018-9

http://iaiglobal.or.id/v03/files/file_berita/Kode\%20Etik\%20Akunta n\%20Profesional.pdf

https://kbbi.web.id/etika

https://www.oxfordlearnersdictionaries.com/definition/english/ethi $\mathrm{c} ? \mathrm{q}=$ ethics 